\title{
Mechanism of gemcitabine-induced suppression of human cholangiocellular carcinoma cell growth
}

\author{
YUKA TOYOTA $^{1}$, HISAKAZU IWAMA ${ }^{3}$, KIYOHITO KATO ${ }^{1}$, JOJI TANI ${ }^{1}$, AKIKO KATSURA ${ }^{1}$, \\ MIWA MIYATA $^{1}$, SHINTARO FUJIWARA ${ }^{1}$, KOJI FUJITA ${ }^{1}$, TEPPEI SAKAMOTO ${ }^{1}$, TAKAYUKI FUJIMORI ${ }^{1}$, \\ RYOICHI OKURA ${ }^{1}$, KIYOYUKI KOBAYASHI ${ }^{1}$, TOMOKO TADOKORO ${ }^{1}$, SHIMA MIMURA ${ }^{1}$, \\ TAKAKO NOMURA $^{1}$, HISAAKI MIYOSHI ${ }^{1}$, ASAHIRO MORISHITA ${ }^{1}$, HIDEKI KAMADA ${ }^{1}$, \\ HIROHITO YONEYAMA ${ }^{1}$, KEIICHI OKANO ${ }^{2}$, YASUYUKI SUZUKI ${ }^{2}$ and TSUTOMU MASAKI $^{1}$ \\ Departments of ${ }^{1}$ Gastroenterology and Neurology, ${ }^{2}$ Gastroenterological Surgery, \\ ${ }^{3}$ Life Science Research Center, Kagawa University, Kagawa 761-0793, Japan
}

Received March 27, 2015; Accepted May 4, 2015

DOI: 10.3892/ijo.2015.3118

\begin{abstract}
Although gemcitabine (2',2'-difluorocytidine monohydrochloride) is a common anticancer agent of cholangiocellular carcinoma (CCC), its growth inhibitory effects and gemcitabine resistance in CCC cells are poorly understood. Our aims were to uncover the mechanism underlying the antitumor effect of gemcitabine and to analyze the mechanism regulating in vitro $\mathrm{CCC}$ cell gemcitabine resistance. In addition, we sought to identify miRNAs associated with the antitumor effects of gemcitabine in CCCs. Using a cell proliferation assay and flow cytometry, we examined the ability of gemcitabine to inhibit cell proliferation in three types of human CCC cell lines (HuCCT-1, Huh28, TKKK). We also employed western blotting to investigate the effects of gemcitabine on cell cycle-related molecules in CCC cells. In addition, we used array chips to assess gemcitabine-mediated changes in angiogenic molecules and activated tyrosine kinase receptors in CCC cells. We used miRNA array chips to comprehensively analyze gemcitabine-induced miRNAs and examined clusters of differentially expressed miRNAs in cells with and without gemcitabine treatment. Gemcitabine inhibited cell proliferation in a dose- and time-dependent manner in HuCCT-1 cells, whereas cell proliferation was unchanged in Huh28 and TKKK cells. Gemcitabine inhibited cell cycle progression in HuCCT-1 cells from G0/G1 to S phase, resulting in G1 cell cycle arrest due to the reduction of cyclin D1 expression. In addition, gemcitabine upregulated the angiogenic molecules
\end{abstract}

Correspondence to: Professor Tsutomu Masaki, Department of Gastroenterology and Neurology Faculty of Medicine, Kagawa University, 1750-1 Ikenobe, Miki-cho, Kita-gun, Kagawa 761-0793, Japan

E-mail: tmasaki@med.kagawa-u.ac.jp

Key words: gemcitabine, cholangiocellular carcinoma, microRNA, angiogenesis, cell cycle
IL-6, IL-8, ENA-78 and MCP-1. In TKKK cells, by contrast, gemcitabine did not arrest the cell cycle or modify angiogenic molecules. Furthermore, in gemcitabine-sensitive HuCCT-1 cells, gemcitabine markedly altered miRNA expression. The miRNAs and angiogenic molecules altered by gemcitabine contribute to the inhibition of tumor growth in vitro.

\section{Introduction}

Cholangiocellular carcinoma (CCC) is the second most common type of primary liver cancer, accounting for 5-10\% of primary liver cancer (1-3). CCC is an aggressive malignancy, and has one of the worst prognosis of the gastrointestinal cancers (4). The incidence and mortality rates of biliary tract cancers, including CCC are increasing worldwide $(1,2,4)$. Since CCC is an enigmatic malignancy of the biliary tract and is highly chemoresistant (6), there is currently no curative treatment other than surgical resection (5).

Recently, gemcitabine (2',2'-difluorocytidine monohydrochloride), a pyrimidine analogue, has been clinically utilized to treat patients with $\mathrm{CCC}$, either as a single agent or in combination with cisplatin (GC) or S-1 (GS). Many studies have demonstrated that gemcitabine is somewhat effective in patients with advanced CCC $(1,2,7,8)$. However, the growth inhibitory effect and gemcitabine resistance of CCC cells are poorly understood (1). Our study aims to investigate the mechanisms underlying the antitumor effect of gemcitabine as well as CCC cell resistance to gemcitabine.

Micro-RNAs (miRNAs) are small, endogenous, noncoding RNAs that can modulate protein expression by regulating translational efficiency or the cleavage of target mRNAs (6). Aberrant miRNA expression is a common feature of various human malignancies (9), and some studies have demonstrated that specific miRNAs are expressed in CCC cells compared with non-malignant cells (10). In addition, many studies, including our own, have reported that miRNAs play an important role in the antitumor effect of anticancer therapeutics $(9,11,12)$. Therefore, the present study was undertaken to identify the miRNAs associated with the antitumor effects of gemcitabine in CCC. 


\section{Materials and methods}

Chemicals. Gemcitabine was purchased from Eli Lilly Japan (Hyogo, Japan). The Cell Counting Kit (CCK-8) was purchased from Dojindo Laboratories (Kumamoto, Japan), and all other chemicals were obtained from Sigma Chemical Co., Ltd. (Tokyo, Japan).

Antibodies. In this study, the following antibodies were used: anti- $\beta$-actin monoclonal antibody (Sigma-Aldrich; A5441, used at 1:3,000); cyclin D1 (Thermo Fisher Scientific, Waltham, MA, USA; RB-9041, used at 1:1,000); Cdk4 (Cell Signaling Technology, Danvers, MA, USA; no 2906, used at 1:1,000); Cdk6 (Santa Cruz Biotechnology, Santa Cruz, CA, USA; sc-177, used at 1:1,000); and secondary horseradish peroxidase (HRP)-linked anti-mouse and anti-rabbit IgG antibodies (GE Healthcare, Buckinghamshire, UK; used at 1:2,000).

Cell lines and cultures. The human CCC cell lines HuCCT-1, Huh28 and TKKK were studied. HuCCT-1 and Huh28 were obtained from the Japanese Cancer Research Resources Bank, and TKKK was provided by the RIKEN BRC through the National Bio-Resource Project of the MEXT, Japan. The cells were passaged in our laboratory for fewer than 6 months, and the cell lines were authenticated by the cell bank using short tandem repeat PCR. HuCCT-1 cells were grown in RPMI-1640 (Gibco, Invitrogen, USA); TKKK was grown in DMEM (High Glucose with L-Glutamine and Phenol Red, Wako, Osaka, Japan), and Huh28 was grown in MEM (Gibco, Invitrogen). These media were supplemented with $10 \%$ fetal bovine serum (Wako, 533-69545, Japan) and penicillin-streptomycin (100 mg/l, Invitrogen), and the cells were cultured in a humidified atmosphere of $5 \% \mathrm{CO}_{2}$ at $37^{\circ} \mathrm{C}$.

Cell proliferation assay. Cell proliferation assays were conducted using CCK-8 according to the manufacturer's instructions, as in our previous studies $(9,11,12)$. Each cell line $\left(1 \times 10^{4}\right)$ was seeded into a well of a 96-well plate and cultured in $100 \mu \mathrm{l}$ of each culture medium. After $24 \mathrm{~h}$, cells were treated with $0.001,0.01,0.1$ or $1 \mu \mathrm{g} / \mathrm{ml}$ gemcitabine or left untreated. At the indicated time points, the medium was changed to $110 \mu \mathrm{l}$ of culture medium supplemented with CCK-8 reagent (10 $\mu$ l CCK-8 and $100 \mu \mathrm{l}$ of each culture medium), and the cells were incubated for $2 \mathrm{~h}$. Absorbance was measured at a wavelength of $450 \mathrm{~nm}$ using an auto-microplate reader.

Preparation of cell lysates. Lysates were collected according to the methods described in our previous studies $(9,11,12)$. All steps were performed at $4^{\circ} \mathrm{C}$. Protein concentrations were measured using a dye-binding protein assay based on the Bradford method (13).

Gel electrophoresis and western blotting. Samples were electrophoresed using 7.5-10\% SDS-PAGE according to the Laemmli method (14), and the proteins were transferred to nitro-cellulose membranes. Western blots were performed according to Towbin et al (15). Briefly, the membranes were incubated with primary antibodies after blocking and then with HRP-conjugated secondary antibodies. Immunoreactive proteins were visualized with an enhanced chemilumines- cence detection system (Perkin Elmer Co.) on X-ray film, as described in our previous studies (16-18).

Flow cytometric analysis. To evaluate the mechanism of growth inhibition by gemcitabine, the cell cycle profile was analyzed following treatment. HuCCT- 1 cells $\left(1.0 \times 10^{6}\right.$ cells in a 6-well plate dish) were treated with $0.1 \mu \mathrm{g} / \mathrm{ml}$ gemcitabine or without gemcitabine for 24-72 h. After treatment, the cells were harvested and fixed in $80 \%$ ethanol, washed with PBS, and stored at $-20^{\circ} \mathrm{C}$ until flow cytometric analysis was conducted as in our previous studies $(9,11,12)$. Prior to analysis, the cells were washed in cold PBS and resuspended in $100 \mu 1$ of PBS and $10 \mu \mathrm{l}$ of RNase A solution $(250 \mu \mathrm{g} / \mathrm{ml})$, followed by incubation for $30 \mathrm{~min}$ at $37^{\circ} \mathrm{C}$. A total of $110 \mu \mathrm{l}$ of propidium iodide (PI) stain $(100 \mu \mathrm{g} / \mathrm{ml})$ was added to each tube, which was then incubated at $4^{\circ} \mathrm{C}$ for at least 30 min prior to analysis. Flow cytometric analysis was conducted using a Cytomics FC 500 flow cytometer (Beckman Coulter) with an argon laser (488 nm). The percentage of cells in different phases of the cell cycle was analyzed using FlowJo software (Tree Star). All experiments were performed in triplicate.

Angiogenic profile analysis using an antibody array. The RayBio $^{\mathrm{TM}}$ Human Angiogenesis Antibody Array 1 kit (catalog no. AAH-ANG-1) was purchased from RayBiotech Inc. (Norcross, GA, USA). The assay for the array was performed according to the manufacturer's instructions as in our previous studies $(9,11,12)$. Briefly, the angiogenesis antibody membranes were incubated in blocking buffer for $30 \mathrm{~min}$. The membranes were then incubated with $1 \mathrm{ml}$ of lysate prepared from cell lines after the protein concentrations were normalized. After washing with TBS containing $0.1 \% \mathrm{v} / \mathrm{v}$ Tween-20 3 times for $10 \mathrm{~min}$, and TBS alone 2 times for $10 \mathrm{~min}$ to remove unbound materials, the membranes were incubated for $2 \mathrm{~h}$ at room temperature with anti-phospho-tyrosine-HRP antibody. The unbound HRP antibody was removed with TBS containing $0.1 \%$ Tween-20. Finally, each array membrane was exposed to X-ray film using a chemiluminescence detection system (Perkin Elmer Co.). The density of the immunoreactive band obtained on this array was analyzed by densitometric scanning (Tlc scanner; Shimizu Co. Ltd., Kyoto, Japan).

Antibody arrays of phosphorylated receptor tyrosine kinase $(p-R T K)$. The RayBio Human Phospho Array kit (catalog no. ARY 001) was purchased from RayBiotech Inc. The assay for p-RTK array was performed according to the manufacturer's instructions, as in our previous studies $(9,11,12)$. Briefly, p-RTK array membranes were blocked with 5\% BSA/TBS (0.01 M Tris-HCl, pH 7.6) for $1 \mathrm{~h}$. Membranes were then incubated with $2 \mathrm{ml}$ of lysate prepared from cell lines after normalization with equal amounts of protein. After washing with TBS containing $0.1 \% \mathrm{v} / \mathrm{v}$ Tween-20 (3 washings for 10 min each) and TBS alone (2 washings for $10 \mathrm{~min}$ each) to remove unbound materials, the membranes were incubated with anti-phospho-tyrosine-HRP antibody for $2 \mathrm{~h}$ at room temperature. The unbound HRP antibody was removed with TBS containing $0.1 \%$ Tween-20. Finally, each array membrane was exposed to X-ray film using a chemiluminescence detection system (Perkin Elmer Co.). The density of the immunoreactive band obtained on the p-RTK array was 


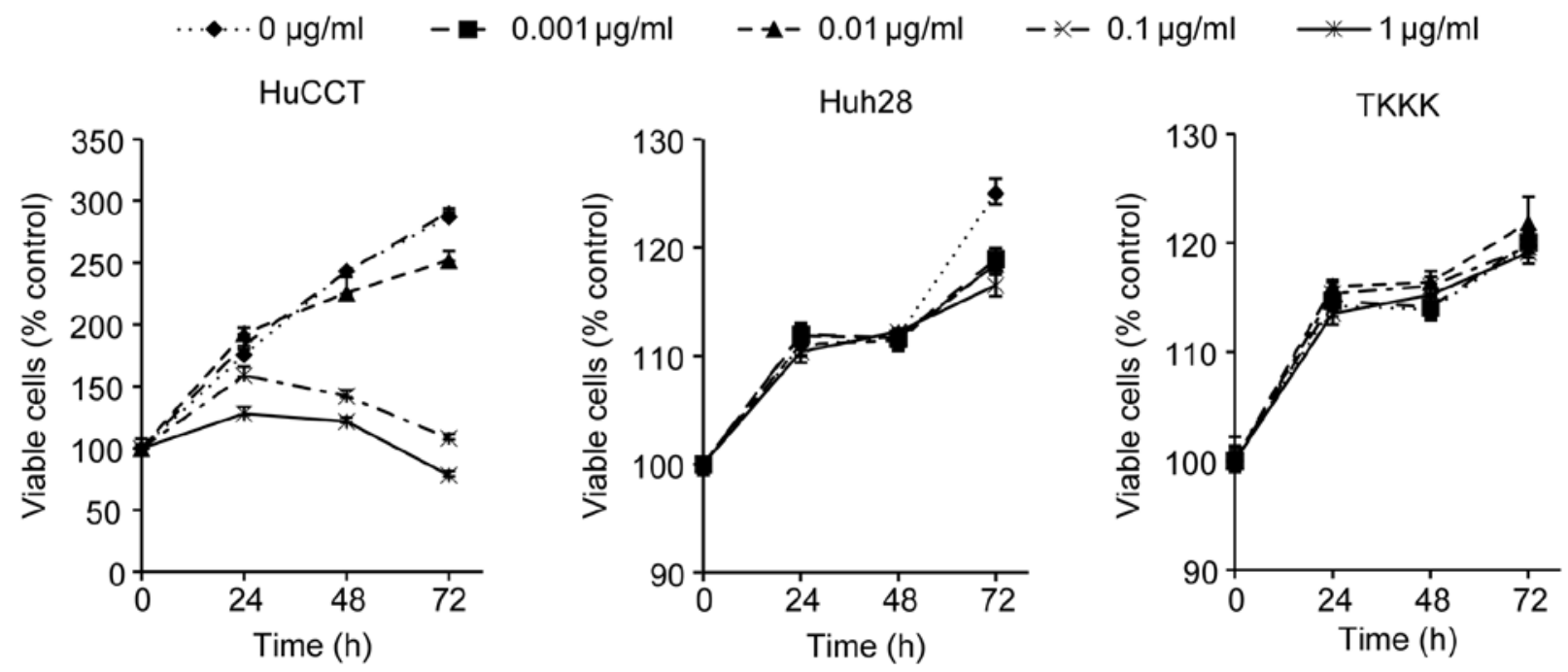

Figure 1. The effects of gemcitabine on proliferation of cultured cholangiocellular carcinoma (CCC) cells. HuCCT-1, Huh28 and TKKK cells were seeded at 10,000 cells per well in 96-well plates, and gemcitabine (GEM; $0,0.001,0.01,0.1$ and $1 \mu \mathrm{g} / \mathrm{ml}$ ) was added to the culture medium at $0 \mathrm{~h}$. A viability assay was conducted daily from 0 to $72 \mathrm{~h}$. The data points represent the mean cell number from 3 independent cultures. The results are expressed as percentages of viable cells compared with the control $(0 \mu \mathrm{g} / \mathrm{ml})$. GEM treatment $(0,0.001,0.01,0.1$ and $1 \mu \mathrm{g} / \mathrm{ml})$ in HuCCT- 1 cells led to a dose- and time-dependent decrease in cell proliferation, while GEM did not inhibit cell proliferation in Huh28 or TKKK cells. The conditions at 48 and $72 \mathrm{~h}$ were significantly different in HuCCT-1 cells compared with the control $(\mathrm{p}<0.05)$.

analyzed by densitometric scanning (Tlc scanner; Shimizu Co. Ltd.).

Analysis of the miRNA array. The samples from the cancer cell lines were processed for total-RNA extraction with a miRNeasy mini kit (Qiagen, Hilden, Germany) according to the manufacturer's instructions as used in our previous studies $(9,11,12,19)$. RNA samples typically showed A260/280 ratios between 1.9 and 2.1, as determined using an Agilent 2100 Bioanalyzer (Agilent Technologies, Santa Clara, CA, USA).

After RNA measurement with an RNA 6000 Nano kit (Agilent Technologies), the samples were labeled using a miRCURY Hy3 Power labeling kit and hybridized on a human miRNA Oligo chip (v.20.0; Toray Industries, Tokyo, Japan). Scanning was performed with a 3D-Gene Scanner 3000 (Toray Industries). 3D-Gene extraction version 1.2 software (Toray Industries) was used to read the raw intensity of the image. To determine the change in miRNA expression between gemcitabine-treated and control samples, the raw data were analyzed via GeneSpringGX v10.0 (Agilent Technologies). Samples were first normalized relative to 28s RNA and baseline-corrected to the median of all samples.

Replicate data were consolidated into two groups: those from gemcitabine-treated cells and those from control cells and were organized using the hierarchical clustering and analysis of variance (ANOVA) functions in the GeneSpring software. Hierarchical clustering was conducted using the clustering function (condition tree) and Euclidean correlation as a distance metric. To search for the miRNAs that varied most prominently across the different groups, two-way ANOVA and asymptotic p-value computation were performed on the samples without any error correction. The p-value cutoff was set to 0.05 . Only changes $>50 \%$ in at least one of the time points for each sample were considered significant. All data were scaled by global normalization, and the significance of differentially expressed miRNAs was analyzed by Student's t-test.
All our micoroarray data in this study were submited as a complete data set to the NCBI Gene Expression Omnibus (GEO), no. GSE 67257. http://www.ncbi.nlm.nih.gov/geo/ query/acc.cgi?token=ghafokcytjgnrwt $\&$ acc $=$ GSE67257

Statistical analyses. All analyses were performed using the computer-assisted JMP8.0 (SAS Institute, Cary, NC, USA). Paired analysis between the groups was performed using Student's t-test. A p-value of 0.05 was considered to indicate a significant difference between groups.

\section{Results}

Gemcitabine inhibits human CCC cell proliferation. To evaluate the effect of gemcitabine on human CCC cell growth activity in vitro, we examined the effect of gemcitabine on the proliferation of the 3 CCC cell lines HuCCT-1, Huh28 and TKKK. The cells were grown in $10 \%$ FBS and treated with $0.001,0.01,0.1,1$ or, as a control, $0 \mu \mathrm{g} / \mathrm{ml}$ gemcitabine. The cell proliferation assay was conducted 3 days after the addition of the reagents. As shown in Fig. 1, gemcitabine (0, 0.001, 0.01, 0.1 and $1 \mu \mathrm{g} / \mathrm{ml}$ ) led to a dose- and time-dependent decrease in cell proliferation in HuCCT-1 cells that was not observed in Huh28 or TKKK cells.

Flow cytometry analysis. To further investigate the inhibition of HuCCT-1 cell proliferation in the presence of gemcitabine, cell cycle progression was examined by flow cytometry. We treated proliferating HuCCT-1 cells with $0.1 \mu \mathrm{g} / \mathrm{ml}$ gemcitabine for different time durations. Following the addition of $0.1 \mu \mathrm{g} / \mathrm{ml}$ gemcitabine, the fraction of HuCCT- 1 cells in the G0/G1 phase increased to 71.1 and $71.5 \%$ after 24 and $48 \mathrm{~h}$, respectively, and the fraction of cells in $\mathrm{S}$ phase decreased to $28.5 \%$ and $27.6 \%$ after 24 and $48 \mathrm{~h}$, respectively (Fig. $2 \mathrm{~A}$ and B). These data suggest that gemcitabine inhibits HuCCT-1 proliferation by preventing cell cycle progression from G0/G1 

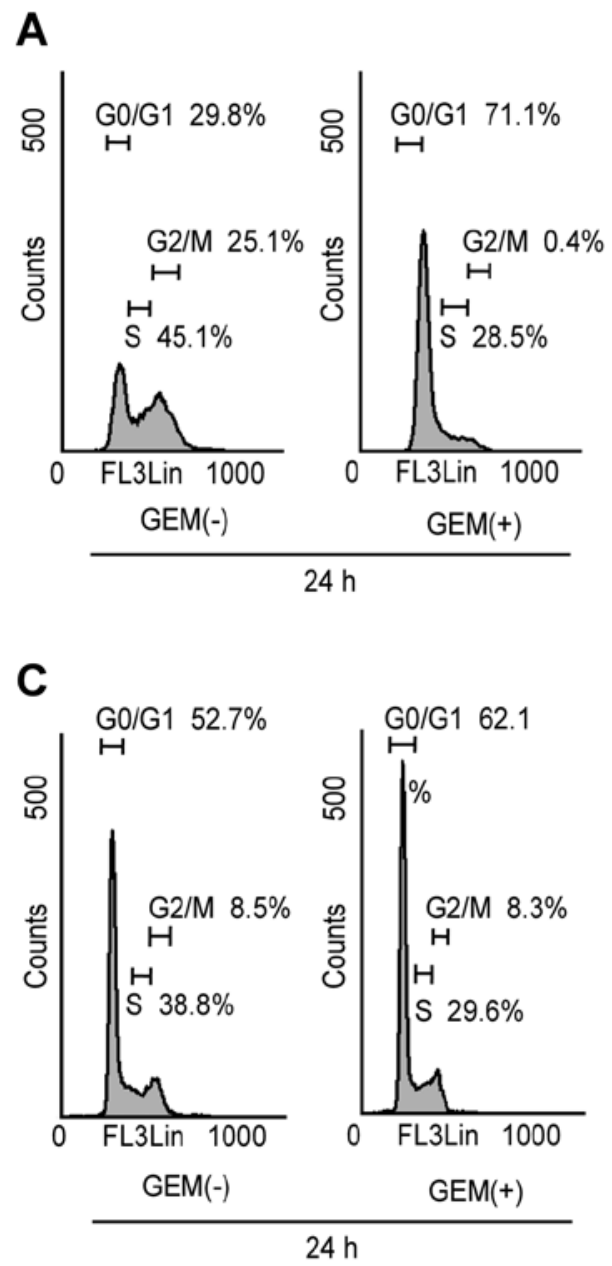
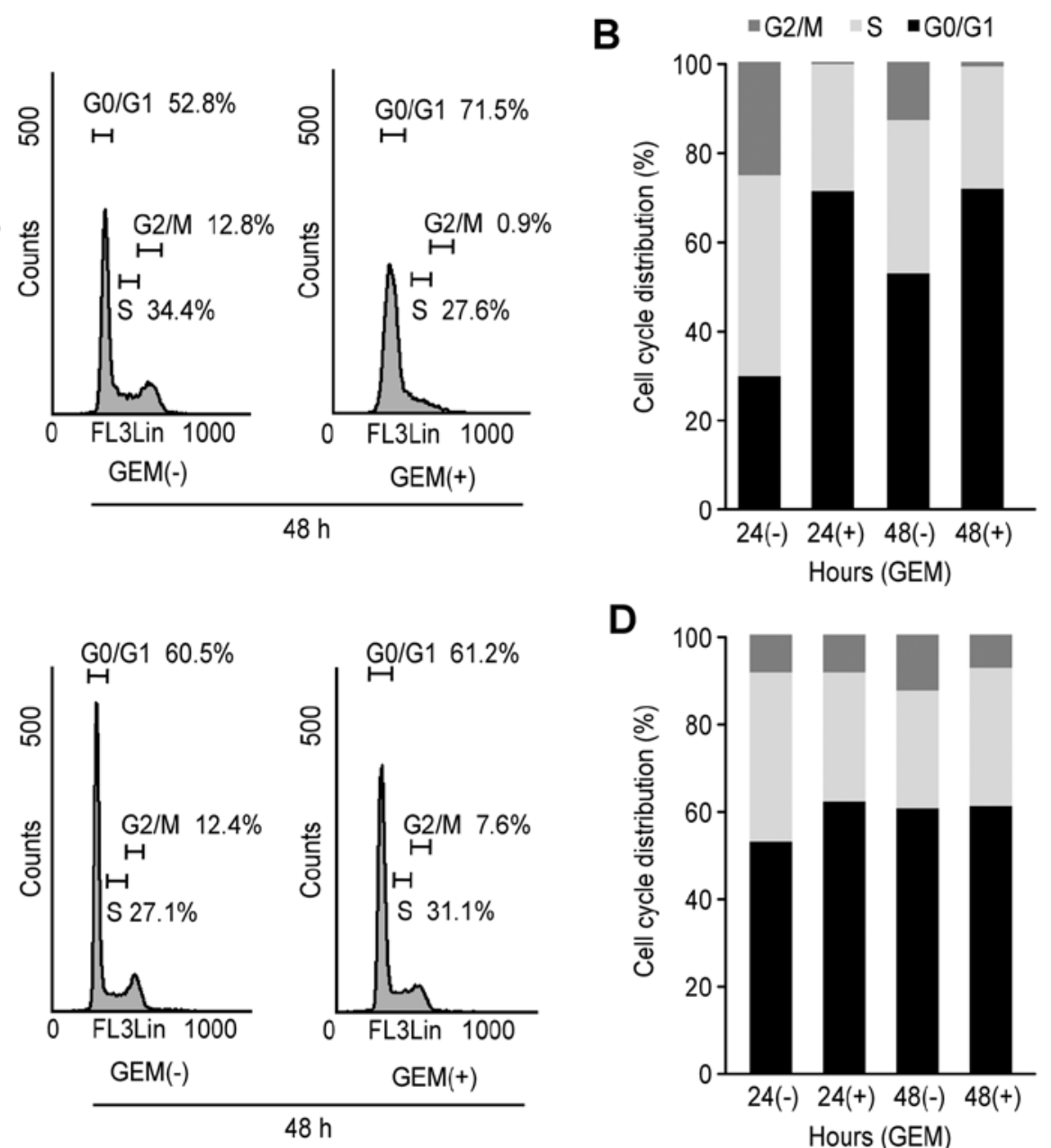

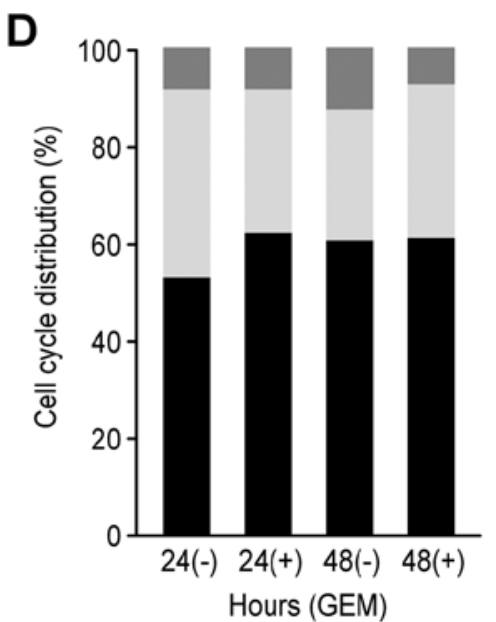

Figure 2. Cell cycle distribution of HuCCT-1 (A and B) and TKKK (C and D) at 24 and $48 \mathrm{~h}$ after the addition of $0.1 \mu \mathrm{g} / \mathrm{ml}$ gemcitabine (GEM). The cell cycle distribution was analyzed by flow cytometry. After $48 \mathrm{~h}$ of $0.1 \mu \mathrm{g} / \mathrm{ml}$ gemcitabine treatment, HuCCT-1 cell cycle progression was inhibited from G0-G1 to S-phase, while this arrest was not observed in TKKK cells. The results are representative of three independent experiments.

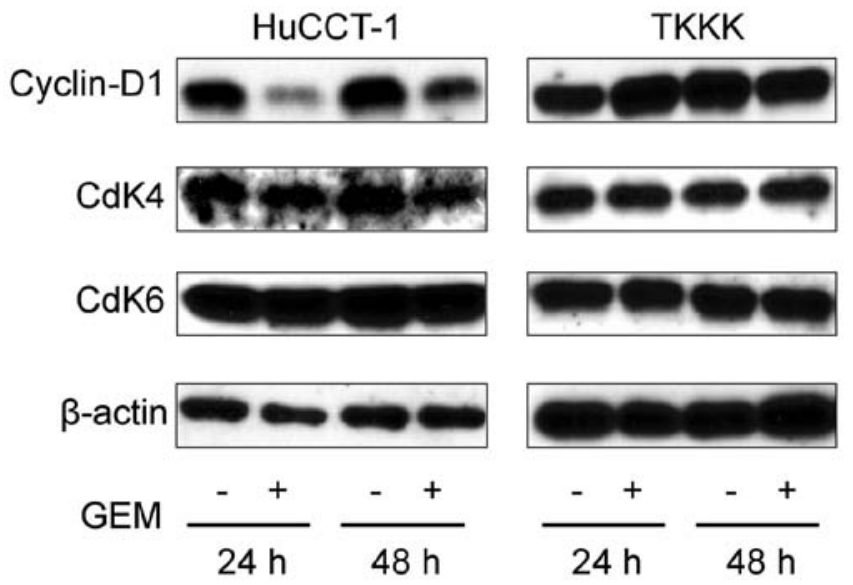

Figure 3. Western blotting of cyclin D1, Cdk4 and Cdk6 in HuCCT-1 and TKKK cells after 24 or $48 \mathrm{~h}$ of $0.1 \mu \mathrm{g} / \mathrm{ml}$ gemcitabine (GEM) treatment. At both 24 and $48 \mathrm{~h}$, cyclin D1 was decreased in treated versus untreated cells. The quantity of the catalytic subunits of cyclin D1, Cdk4 and Cdk6 did not differ in the treated cells at either time point. The expression of cyclin D1, Cdk4 and Cdk6 remained unchanged in TKKK cells. $\beta$-actin was used as a loading control.

into $\mathrm{S}$ phase, resulting in $\mathrm{G} 1$ cell cycle arrest. The effects of gemcitabine in HuCCT-1 based on this flow cytometric analysis are consistent with the cell proliferation assay, as shown in Fig. 1. In contrast, flow cytometric analysis suggested that gemcitabine treatment of TKKK cells did not result in G1 cell cycle arrest (Fig. 2C and D).

Effects of gemcitabine on cell cycle regulatory proteins in $H u C C T-1$. To further study the effects of gemcitabine on the cell cycle, the expression of cell cycle-related proteins was studied using western blots in treated and untreated HuCCT-1 and TKKK cells. Cells were treated with 0.1 or $0 \mu \mathrm{g} / \mathrm{ml}$ gemcitabine for 24 or $48 \mathrm{~h}$. Cyclin D1 expression at the G0-G1 transition was notably decreased at $24 \mathrm{~h}$ and slightly apparent at $48 \mathrm{~h}$ in treated versus untreated HuCCT-1 cells (Fig. 3). In addition, the catalytic subunits of cyclin D1, namely, Cdk4 and Cdk6, were not changed after 24 or $48 \mathrm{~h}$ with or without $0.1 \mu \mathrm{g} / \mathrm{ml}$ gemcitabine treatment in HuCCT-1 (Fig. 3). The expression of cyclin D1, Cdk4 and Cdk6 remained unchanged in TKKK cells, which are not sensitive to gemcitabine. Based on these results, the gemcitabine-mediated anti-proliferative effects and cell cycle arrest were due to the reduction of cyclin D1.

Differences in angiogenesis-related protein expression in HuCCT-1 and TKKK cells with or without gemcitabine 
A

\begin{tabular}{|c|c|c|c|c|c|c|c|}
\hline POS & POS & NEG & NEG & Angiogenin & EGF & ENA-78 & b FGF \\
\hline GRO & IFN-Y & IGF-1 & IL-6 & IL-8 & LEPTIN & MCP-1 & PDGF-88 \\
\hline PIGF & RANTES & TGF- $\beta 1$ & TIMP-1 & TIMP-2 & Thrombopoietin & VEGF & VEGF-D \\
\hline & & & & & & NEG & POS \\
\hline
\end{tabular}

B

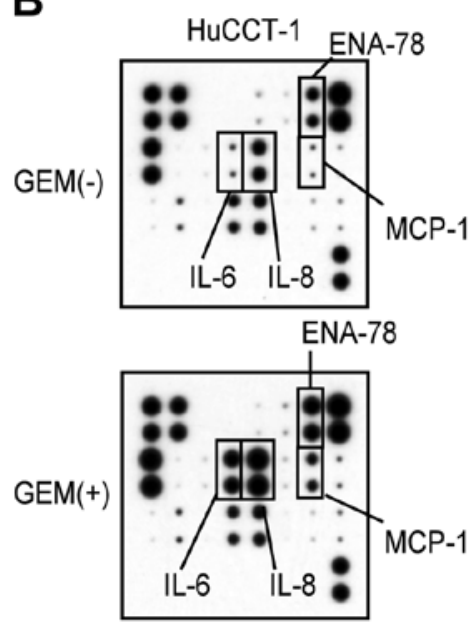

C

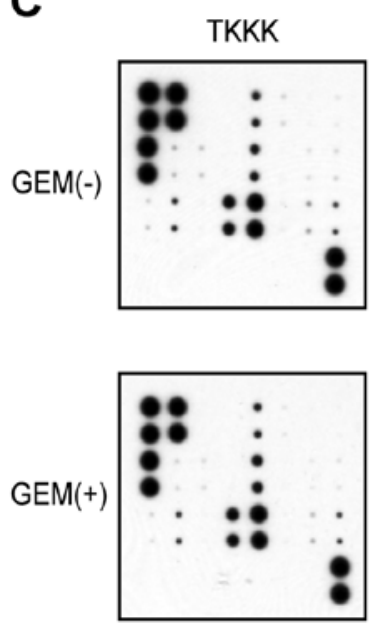

D

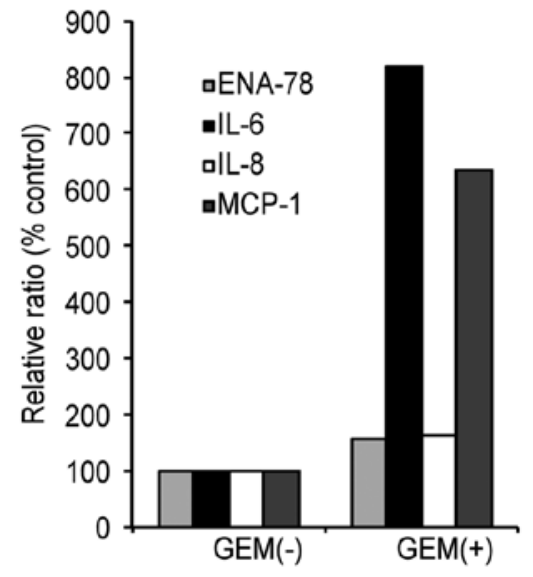

Figure 4. (A) Template showing the location of antibodies for angiogenesis-related protein spotted onto the Ray Bio Human Cytokine antibody array kit. (B and C) Representative expression of antibodies for angiogenesis-related protein in HuCCT-1 and TKKK cells with or without gemcitabine (GEM) treatment. In HuCCT-1 cells, the increased expression of IL-6, IL-8, ENA-78 and MCP-1 was detected in cells treated with GEM. In TKKK cells, the expression of all angiogenesis-related proteins did not change in treated versus untreated cells. (D) The densities of IL-6, IL-8, ENA-78 and MCP-1 obtained from the membrane array were analyzed in HuCCT-1. The densitometric ratios of gemcitabine-treated to untreated cells in ENA-78, IL-6, IL-8 and MCP-1 spots were $156,817,165$ and $633 \%$.

treatment. We used an angiogenesis antibody array system to identify the key angiogenesis-related proteins in terms of the antitumor effect of gemcitabine. Using an antibody array (Fig. 4A), we simultaneously screened the expression of 20 angiogenic molecules in HuCCT-1 and TKKK cells with or without $0.1 \mu \mathrm{g} / \mathrm{ml}$ gemcitabine treatment. In HuCCT-1 cells, which were sensitive to gemcitabine, the expression of interleukin (IL)-6, IL-8, ENA-78 and MCP-1 was increased after $48 \mathrm{~h}$ of treatment with $0.1 \mu \mathrm{g} / \mathrm{ml}$ gemcitabine, as detected by the protein array (Fig. 4B). In TKKK cells, which are resistant to gemcitabine, there was no difference in the expression of angiogenic molecules between gemcitabine-treated and untreated cells (Fig. 4C). The IL-6, IL-8, ENA-78 and MCP-1 densities obtained from the membrane array were analyzed using the Kodak Image Station (Eastman Kodak), and the densitometric ratios of gemcitabine-treated to non-treated HuCCT-1 cells for IL-6, IL-8, ENA-78 and MCP-1 spots were $817,165,156$ and $633 \%$, respectively (Fig. 4D).

Differences in phosphorylated-receptor tyrosine kinases p-(RTKs) in HuCCT-1 and TKKK cells with or without gemcitabine treatment. Having established the antitumor effects of gemcitabine in CCC cell lines, we next used a phosphorylated-RTK array system to identify the key RTKs in terms of antitumor effects. Using an antibody array (Fig. 5A), we simultaneously screened the expression of 42 different
RTKs in HuCCT-1 and TKKK cells after $48 \mathrm{~h}$ with or without $0.1 \mu \mathrm{g} / \mathrm{ml}$ gemcitabine treatment. RTKs activation was not changed by gemcitabine treatment in HuCCT-1 or TKKK cells (Fig. 5B and C).

Differences in miRNA expression in HuCCT-1 cells with or without gemcitabine treatment in vitro. Using a custom microarray platform, we studied the in vitro expression levels of 2555 human miRNA probes in two cell lines (gemcitabinesensitive HuCCT-1 cells and gemcitabine-resistant TKKK cells) with or without gemcitabine treatment. Unsupervised hierarchical clustering analysis using Pearson's correlation demonstrated that HuCCT-1 cell lines treated in vitro with gemcitabine, clustered together, separate from untreated cell lines (Fig. 6). These subsets of 137 microRNAs in the HuCCT-1 cell lines exhibited significantly $(\mathrm{p}<0.05)$ different expression levels between the gemcitabine-treated and control groups. As shown in Table I, when in vitro miRNA expression was studied in gemcitabine-treated and untreated HuCCT-1 cells, 95 miRNAs were significantly upregulated after $48 \mathrm{~h}$, while 11 miRNAs were downregulated. These 106 HuCCT-1 miRNAs exhibited a $>1.5$-fold alteration in expression levels between the gemcitabine-treated and control groups.

In TKKK cells, which were resistant to gemcitabine, 1 miRNA was upregulated and 16 miRNAs were downregulated (Table II). In Tables I and II, miR-3181 was 
A

\begin{tabular}{|l|l|l|l|l|l|l|l|l|l|l|c|}
\hline POS & & & & & & & & & & & POS \\
\hline EGF R & ErbB2 & ErbB3 & ErbB4 & FGF R1 & $\begin{array}{c}\text { FGF } \\
\text { R2 } \alpha\end{array}$ & FGF R3 & FGF R4 & $\begin{array}{c}\text { Insulin } \\
\text { R }\end{array}$ & $\begin{array}{c}\text { IGF- } \\
\text { IR }\end{array}$ & Axl & Dtk \\
\hline Mer & HGF R & MSP R & $\begin{array}{c}\text { PDGF } \\
\text { Ra }\end{array}$ & $\begin{array}{c}\text { PDGF } \\
\text { R3 }\end{array}$ & SCF R & Flt-3 & $\begin{array}{c}\text { M-CSF } \\
\text { R }\end{array}$ & C-Ret & ROR1 & ROR2 & Tie-1 \\
\hline Tie-2 & TrkA & TrkB & TrkC & $\begin{array}{c}\text { VEGF } \\
\text { R1 }\end{array}$ & $\begin{array}{c}\text { VEGF } \\
\text { R2 }\end{array}$ & $\begin{array}{c}\text { VEGF } \\
\text { R3 }\end{array}$ & MuSK & EphA1 & EphA2 & EphA3 & EphA4 \\
\hline EphA6 & EphA7 & EphB1 & EphB2 & EphB4 & EphB6 & $\begin{array}{c}\text { Mouse } \\
\text { IgG1 }\end{array}$ & $\begin{array}{c}\text { Mouse } \\
\text { IgG2A }\end{array}$ & $\begin{array}{c}\text { Mouse } \\
\text { IgG2B }\end{array}$ & $\begin{array}{c}\text { Goat } \\
\text { IgG }\end{array}$ & PBS & \\
\hline POS & & & & & & & & & & & POS \\
\hline
\end{tabular}

B
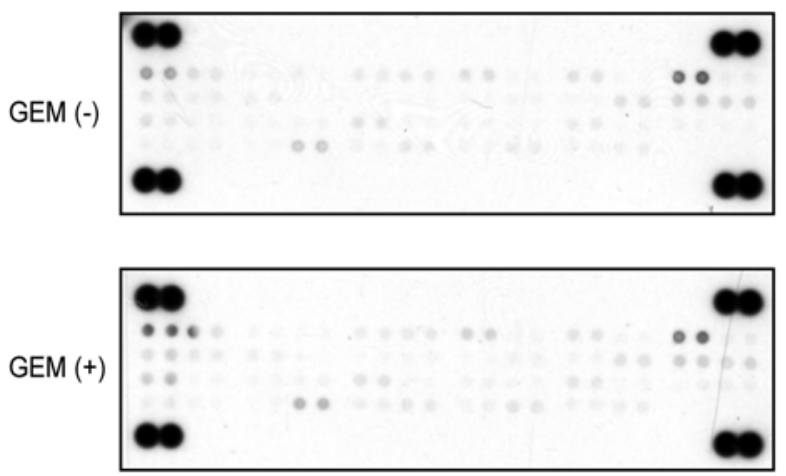

C
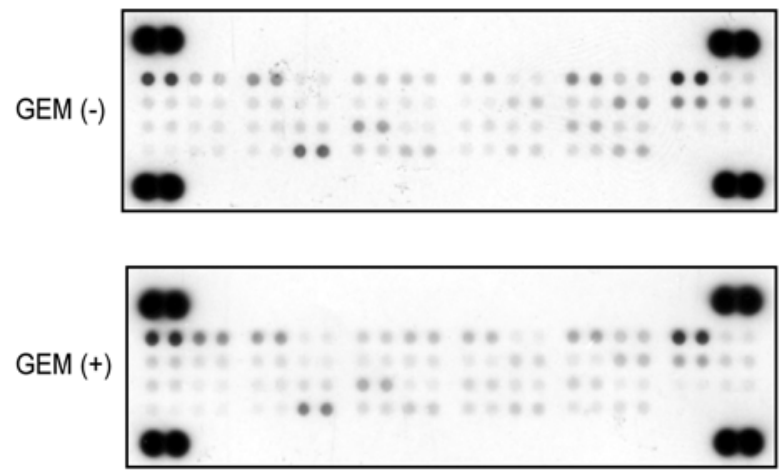

Figure 5. (A) Template showing the location of 42 tyrosine kinase antibodies spotted onto the Ray Bio Human phospho array kit. (B and C) Representative expression of various phosphorylated tyrosine kinase receptors in HuCCT-1 and TKKK cells with or without gemcitabine (GEM) treatment. The activation of 42 tyrosine kinases was not changed by GEM treatment in HuCCT-1 or TKKK cells.

downregulated in both cell lines (gemcitabine-sensitive HuCCT-1 and gemcitabine-resistant TKKK). The miRNAs miR-6087, miR-3651 and miR-664b-3p were upregulated in gemcitabine-treated HuCCT-1 cells (Tables I and II) and downregulated in gemcitabine-treated TKKK cells (Table III).

\section{Discussion}

The incidence of $\mathrm{CCC}$, the second most common tumor of primary liver cancers in adults, is rising worldwide (1). Currently, there is no curative treatment other than surgical resection $(2,5,20)$. Conventional chemotherapy is not always effective, because CCC is a highly chemo-resistant malignancy $(2,6)$. Therefore, it is necessary to study the mechanism of growth inhibitory effect and gemcitabine resistance in CCC cells.

In the present study, gemcitabine treatment in the three human cell lines led to a strong, dose-dependent inhibition of cell proliferation in only HuCCT-1 cells. In the gemcitabinesensitive HuCCT-1 cells, the anti-proliferative effect of gemcitabine led to G1 arrest through a reduction of cyclin D1. Although some studies have reported that gemcitabine could inhibit cell-phase transitioning during G1 phase $(1,21)$, to date, there are no studies on cyclin $\mathrm{D} 1$ reduction as an anticancer effect of gemcitabine in CCC cells. This study revealed that gemcitabine induced a cell cycle arrest at the G0/G1 phase by reducing cyclin D1 levels in HuCCT-1 cells in vitro. Gemcitabine did not exert an anti-proliferative effect on the other cell lines, Huh28 and TKKK. These results support that some CCCs might be highly chemoresistant to clinical treatment.

Angiogenic profile analysis revealed that in gemcitabinesensitive HuCCT-1 cells, gemcitabine upregulated IL-6, IL-8, ENA-78 and MCP-1. IL-6, IL-8, ENA-78 and MCP-1, which are not only related to angiogenesis but are also involved in the promotion of cell proliferation (22-25). Studies suggest that these molecules are upregulated in various cancers including cholangiocarcinoma (22-25). In addition, IL-8, IL-6 and MCP-1 overexpression was associated with a worse prognosis of patients with various cancers $(22,23,25)$. These events suggest that CCC patients might acquire gemcitabine resistance, even if they are initially sensitive. Acquired gemcitabine resistance might be due to the gemcitabine-induced upregulation of IL-6, IL-8, ENA-78 and MCP-1. These data suggest that the application of gemcitabine for CCC treatment might be limited.

miRNAs are small, endogenous, noncoding RNA sequences that can modulate protein expression by regulating translational efficiency or the cleavage of target mRNA molecules (6). To identify the miRNAs associated with antitumor effect and acquired gemcitabine resistance, we used a miRNA array to measure the variation in HuCCT-1 cell lines cultured with or without gemcitabine. In the cluster analysis, we demonstrated that treating HuCCT-1 with gemcitabine affects various miRNAs. In the present study, sets of miRNAs had 


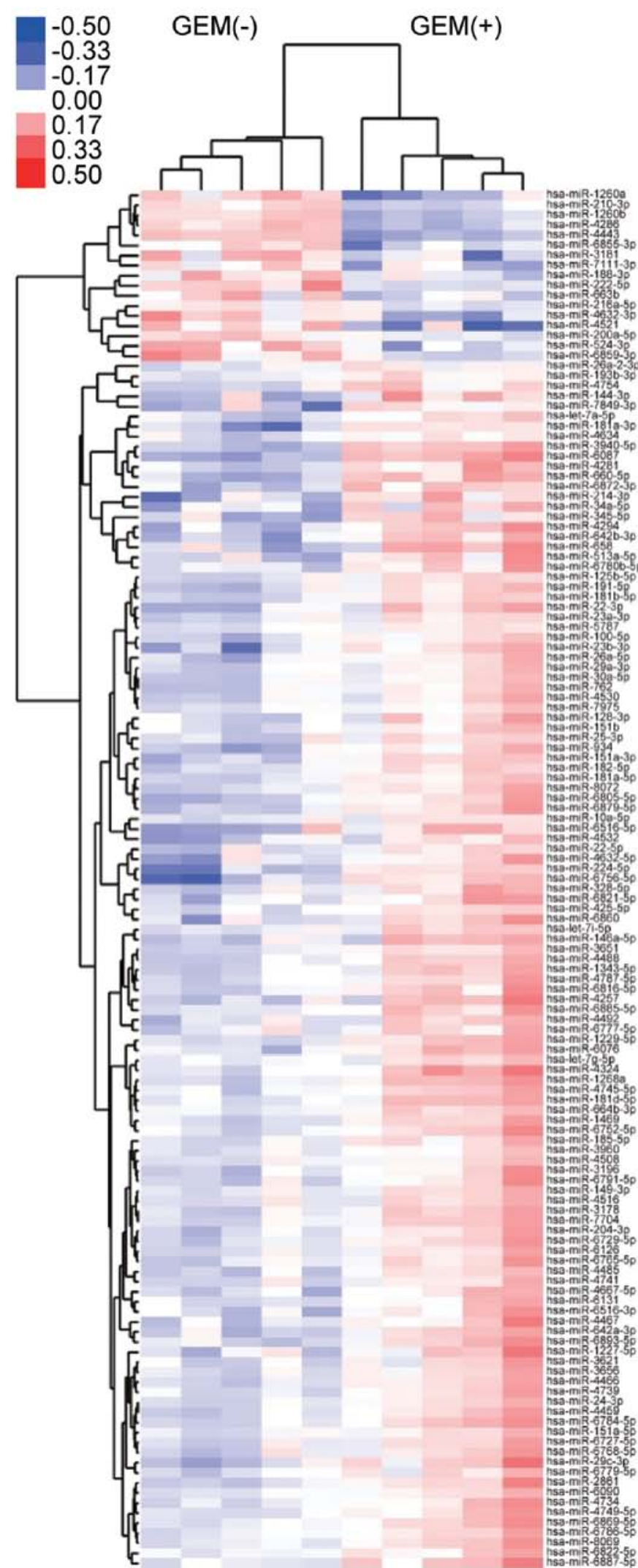

Figure 6. Hierarchical clustering of HuCCT-1 cells with and without gemcitabine (GEM) treatment. HuCCT-1 cells clustered according to the expression profiles of 137 miRNAs that were differentially expressed between treated and untreated HuCCT-1 cells. The analyzed samples are shown in columns, and the miRNAs are presented in rows. The miRNA clustering tree is shown on the left, and the sample-clustering tree appears at the top. The color scale shown at the top illustrates the relative expression level of miRNAs; red represents a high expression level, and blue represents a low expression level.
Table I. Expression changes and chromosomal locations of miRNAs in HuCCT-1 cells (gemcitabine sensitive) treated with gemcitabine compared with untreated cells.

\begin{tabular}{|c|c|c|c|}
\hline \multirow{2}{*}{$\begin{array}{l}\text { Upregulated } \\
\text { miRNA }\end{array}$} & \multicolumn{2}{|c|}{ Fold (treated/untreated) } & \multirow{2}{*}{$\begin{array}{l}\text { Chromosomal } \\
\text { localization }\end{array}$} \\
\hline & Mean \pm SD & p-value & \\
\hline hsa-miR-6087 & $3.66 \pm 0.651$ & 0.00002 & $\mathrm{Xq} 22.3$ \\
\hline hsa-miR-23b-3p & $2.74 \pm 1.031$ & 0.01229 & $9 q 22.23$ \\
\hline hsa-miR-6756-5p & $2.33 \pm 0.847$ & 0.00502 & $11 \mathrm{q} 23.3$ \\
\hline hsa-miR-22-3p & $2.33 \pm 0.875$ & 0.01442 & $17 \mathrm{p} 13.3$ \\
\hline hsa-miR-3940-5p & $2.21 \pm 0.685$ & 0.00004 & $19 \mathrm{p} 13.3$ \\
\hline hsa-miR-224-5p & $2.05 \pm 0.534$ & 0.00201 & $\mathrm{Xq} 28$ \\
\hline hsa-miR-29c-3p & $1.92 \pm 0.736$ & 0.01513 & $1 q 32.2$ \\
\hline hsa-miR-6805-5p & $1.91 \pm 0.609$ & 0.00568 & $19 q 13.42$ \\
\hline hsa-miR-2861 & $1.91 \pm 0.832$ & 0.01377 & 9 \\
\hline hsa-miR-660-5p & $1.91 \pm 0.461$ & 0.00051 & Xp11.23 \\
\hline hsa-miR-7704 & $1.89 \pm 0.402$ & 0.00804 & $2 q 31.1$ \\
\hline hsa-miR-4257 & $1.88 \pm 0.976$ & 0.02902 & $1 q 21.2$ \\
\hline hsa-miR-658 & $1.88 \pm 0.082$ & 0.0168 & $22 q 13.1$ \\
\hline hsa-miR-6784-5p & $1.86 \pm 0.409$ & 0.00642 & $17 \mathrm{q} 21.31$ \\
\hline hsa-let-7a-5p & $1.85 \pm 0.945$ & 0.01319 & $\begin{array}{l}9 q 22.32 / 11 q 24.1 / \\
22 q 13.31\end{array}$ \\
\hline hsa-miR-146a-5p & $1.84 \pm 0.661$ & 0.02201 & $5 q 33.3$ \\
\hline hsa-miR-8072 & $1.83 \pm 0.371$ & 0.00516 & $12 q 24.31$ \\
\hline hsa-miR-4294 & $1.82 \pm 0.765$ & 0.00554 & $10 \mathrm{q} 11.23$ \\
\hline hsa-miR-4488 & $1.82 \pm 0.291$ & 0.00227 & $11 q 12.2$ \\
\hline hsa-miR-181a-3p & $1.81 \pm 0.666$ & 0.00896 & 1q32.1 \\
\hline hsa-miR-3196 & $1.81 \pm 0.580$ & 0.0311 & $20 q 13.33$ \\
\hline hsa-miR-642b-3p & $1.80 \pm 0.752$ & 0.00487 & $19 q 13.32$ \\
\hline hsa-miR-4324 & $1.80 \pm 0.537$ & 0.00874 & $19 \mathrm{q} 13.33$ \\
\hline hsa-miR-214-3p & $1.78 \pm 0.966$ & 0.01726 & $1 \mathrm{q} 24.3$ \\
\hline hsa-miR-6729-5p & $1.77 \pm 0.477$ & 0.00946 & $1 \mathrm{p} 36.22$ \\
\hline hsa-miR-3178 & $1.77 \pm 0.389$ & 0.00752 & $16 \mathrm{p} 13.3$ \\
\hline hsa-miR-204-3p & $1.76 \pm 0.350$ & 0.01501 & $9 \mathrm{q} 21.12$ \\
\hline hsa-miR-1268a & $1.73 \pm 0.355$ & 0.00168 & $15 q 11.2$ \\
\hline hsa-miR-191-5p & $1.72 \pm 0.416$ & 0.00965 & $3 \mathrm{p} 21.31$ \\
\hline hsa-miR-4459 & $1.72 \pm 0.277$ & 0.00785 & $5 q 11.2$ \\
\hline hsa-miR-100-5p & $1.72 \pm 0.367$ & 0.01228 & $11 \mathrm{q} 24.1$ \\
\hline hsa-miR-513a-5p & $1.71 \pm 0.753$ & 0.02639 & $\mathrm{Xq} 27.3$ \\
\hline hsa-miR-4787-5p & $1.70 \pm 0.473$ & 0.02273 & $3 \mathrm{p} 21.2$ \\
\hline hsa-miR-762 & $1.70 \pm 0.235$ & 0.02553 & $16 \mathrm{p} 11.2$ \\
\hline hsa-miR-6879-5p & $1.70 \pm 0.563$ & 0.00542 & $11 \mathrm{q} 13.1$ \\
\hline hsa-miR-4281 & $1.69 \pm 0.491$ & 0.00879 & $5 q 35.2$ \\
\hline hsa-miR-6516-5p & $1.69 \pm 0.527$ & 0.02887 & $17 \mathrm{q} 25.2$ \\
\hline hsa-miR-642a-3p & $1.69 \pm 0.467$ & 0.00551 & $19 q 13.32$ \\
\hline hsa-miR-1227-5p & $1.68 \pm 0.482$ & 0.04756 & $19 \mathrm{p} 13.3$ \\
\hline hsa-miR-328-5p & $1.68 \pm 0.390$ & 0.02023 & $16 \mathrm{q} 22.1$ \\
\hline hsa-miR-6893-5p & $1.68 \pm 0.708$ & 0.01314 & $8 \mathrm{q} 24.3$ \\
\hline hsa-miR-29a-3p & $1.67 \pm 0.360$ & 0.04206 & $7 \mathrm{q} 32.3$ \\
\hline hsa-miR-6860 & $1.65 \pm 0.533$ & 0.03083 & 11 \\
\hline hsa-miR-6869-5p & $1.65 \pm 0.490$ & 0.01637 & $20 \mathrm{p} 13$ \\
\hline hsa-miR-23a-3p & $1.65 \pm 0.481$ & 0.02188 & $19 \mathrm{p} 13.13$ \\
\hline hsa-miR-4466 & $1.65 \pm 0.309$ & 0.00507 & $6 q 25.3$ \\
\hline
\end{tabular}


Table I. Continued.

\begin{tabular}{|c|c|c|c|}
\hline \multirow{2}{*}{$\begin{array}{l}\text { Upregulated } \\
\text { miRNA }\end{array}$} & \multicolumn{2}{|c|}{ Fold (treated/untreated) } & \multirow{2}{*}{$\begin{array}{c}\text { Chromosomal } \\
\text { localization }\end{array}$} \\
\hline & Mean \pm SD & p-value & \\
\hline hsa-miR-151a-3p & $1.65 \pm 0.390$ & 0.00371 & $8 \mathrm{q} 24.3$ \\
\hline hsa-miR-24-3p & $1.64 \pm 0.231$ & 0.01055 & $\begin{array}{l}9 \mathrm{q} 22.32 / \\
19 \mathrm{p} 13.12\end{array}$ \\
\hline hsa-miR-144-3p & $1.64 \pm 0.318$ & 0.0193 & $17 \mathrm{q} 11.2$ \\
\hline hsa-miR-4467 & $1.64 \pm 0.603$ & 0.04342 & $7 q 22.1$ \\
\hline hsa-miR-6816-5p & $1.64 \pm 0.463$ & 0.01588 & $22 q 11.21$ \\
\hline hsa-miR-6752-5p & $1.63 \pm 0.641$ & 0.02179 & $11 \mathrm{q} 13.2$ \\
\hline hsa-miR-1343-5p & $1.62 \pm 0.342$ & 0.01088 & $11 \mathrm{p} 13$ \\
\hline hsa-miR-26a-5p & $1.62 \pm 0.412$ & 0.03867 & $3 p 22.2 / 12 q 14.1$ \\
\hline hsa-miR-1469 & $1.62 \pm 0.425$ & 0.00392 & $15 q 26.2$ \\
\hline hsa-miR-6768-5p & $1.62 \pm 0.190$ & 0.04194 & $16 \mathrm{p} 13.3$ \\
\hline hsa-miR-4739 & $1.61 \pm 0.440$ & 0.01531 & $17 \mathrm{q} 25.3$ \\
\hline hsa-miR-6076 & $1.61 \pm 0.569$ & 0.00643 & $14 \mathrm{q} 21.3$ \\
\hline hsa-miR-4632-5p & $1.61 \pm 0.444$ & 0.04771 & $1 \mathrm{p} 36.22$ \\
\hline hsa-miR-125b-5p & $1.61 \pm 0.273$ & 0.00715 & $\begin{array}{l}\text { 11q24.1/ } \\
21 q 21.1\end{array}$ \\
\hline hsa-miR-3621 & $1.60 \pm 0.421$ & 0.03484 & $9 q 34.3$ \\
\hline hsa-miR-1229-5p & $1.60 \pm 0.378$ & 0.00114 & $5 q 35.3$ \\
\hline hsa-miR-6727-5p & $1.60 \pm 0.289$ & 0.02885 & $1 \mathrm{p} 36.33$ \\
\hline hsa-miR-345-5p & $1.60 \pm 0.334$ & 0.01108 & $14 \mathrm{q} 32.2$ \\
\hline hsa-miR-6887-5p & $1.59 \pm 0.489$ & 0.00986 & $19 q 13.12$ \\
\hline hsa-miR-934 & $1.59 \pm 0.475$ & 0.00804 & $\mathrm{Xq} 26.3$ \\
\hline hsa-miR-6872-3p & $1.58 \pm 0.407$ & 0.00243 & $3 p 21.31$ \\
\hline hsa-miR-6821-5p & $1.58 \pm 0.417$ & 0.02227 & $22 q 13.33$ \\
\hline hsa-miR-4530 & $1.58 \pm 0.331$ & 0.04933 & $19 q 13.2$ \\
\hline hsa-miR-7975 & $1.58 \pm 0.386$ & 0.04948 & $19 q 13.42$ \\
\hline hsa-miR-4492 & $1.57 \pm 0.391$ & 0.02715 & $11 \mathrm{q} 23.3$ \\
\hline hsa-miR-8069 & $1.57 \pm 0.430$ & 0.01413 & 21 \\
\hline hsa-miR-4516 & $1.57 \pm 0.282$ & 0.03403 & $16 \mathrm{p} 13.3$ \\
\hline hsa-miR-4532 & $1.56 \pm 0.456$ & 0.04442 & $20 \mathrm{q} 13.32$ \\
\hline hsa-miR-4734 & $1.56 \pm 0.534$ & 0.03834 & $17 q 12$ \\
\hline hsa-miR-3656 & $1.56 \pm 0.295$ & 0.02295 & $11 \mathrm{q} 23.3$ \\
\hline hsa-miR-6765-5p & $1.56 \pm 0.331$ & 0.02757 & $14 \mathrm{q} 32.33$ \\
\hline hsa-miR-181d-5p & $1.56 \pm 0.381$ & 0.00426 & $19 \mathrm{p} 13.13$ \\
\hline hsa-miR-6516-3p & $1.56 \pm 0.498$ & 0.03436 & $17 \mathrm{q} 25.2$ \\
\hline hsa-miR-4667-5p & $1.55 \pm 0.507$ & 0.01382 & $9 \mathrm{p} 13.3$ \\
\hline hsa-miR-6885-5p & $1.55 \pm 0.498$ & 0.01662 & $19 \mathrm{p} 13.3$ \\
\hline hsa-miR-6791-5p & $1.54 \pm 0.329$ & 0.0392 & $19 p 13.3$ \\
\hline hsa-miR-6780b-5p & $1.54 \pm 0.458$ & 0.02333 & $6 \mathrm{p} 21.1$ \\
\hline hsa-miR-181b-5p & $1.54 \pm 0.176$ & 0.00073 & $1 \mathrm{q} 32.1 / 9 \mathrm{q} 33.3$ \\
\hline hsa-miR-4485 & $1.54 \pm 0.215$ & 0.00333 & 11 \\
\hline hsa-miR-30a-5p & $1.54 \pm 0.198$ & 0.03159 & $6 q 13$ \\
\hline hsa-miR-34a-5p & $1.54 \pm 0.490$ & 0.02875 & $1 \mathrm{p} 36.22$ \\
\hline hsa-miR-3651 & $1.53 \pm 0.240$ & 0.00232 & $9 q 22.31$ \\
\hline hsa-miR-7849-3p & $1.53 \pm 0.373$ & 0.02978 & $4 q 31.22$ \\
\hline hsa-miR-6786-5p & $1.52 \pm 0.416$ & 0.02395 & $17 \mathrm{q} 25.3$ \\
\hline hsa-miR-4745-5p & $1.51 \pm 0.365$ & 0.01286 & $19 p 13.3$ \\
\hline hsa-miR-4749-5p & $1.50 \pm 0.467$ & 0.02088 & $19 q 13.33$ \\
\hline hsa-miR-128-3p & $1.50 \pm 0.597$ & 0.03967 & $2 \mathrm{q} 21.3 / 3 \mathrm{p} 22.3$ \\
\hline hsa-miR-664b-3p & $1.50 \pm 0.376$ & 0.00448 & $\mathrm{Xq} 28$ \\
\hline hsa-miR-6090 & $1.50 \pm 0.333$ & 0.02555 & $11 \mathrm{q} 24.3$ \\
\hline
\end{tabular}

Table I. Continued.

\begin{tabular}{|c|c|c|c|}
\hline \multirow{2}{*}{$\begin{array}{l}\text { Downregulated } \\
\text { miRNA }\end{array}$} & \multicolumn{2}{|c|}{ Fold (treated/untreated) } & \multirow{2}{*}{$\begin{array}{c}\text { Chromosomal } \\
\text { localization }\end{array}$} \\
\hline & Mean \pm SD & p-value & \\
\hline hsa-miR-1260b & $0.37 \pm 0.069$ & 0.00014 & $11 \mathrm{q} 21$ \\
\hline hsa-miR-4443 & $0.39 \pm 0.056$ & $3.60 \mathrm{E}-06$ & $3 \mathrm{p} 21.31$ \\
\hline hsa-miR-4286 & $0.39 \pm 0.051$ & 0.0002 & $8 p 23.1$ \\
\hline hsa-miR-1260a & $0.43 \pm 0.099$ & 0.00599 & $14 q 24.3$ \\
\hline hsa-miR-4521 & $0.53 \pm 0.211$ & 0.0102 & 17 \\
\hline hsa-miR-222-5p & $0.62 \pm 0.170$ & 0.00432 & Xp11.3 \\
\hline hsa-miR-3181 & $0.63 \pm 0.175$ & 0.0266 & $16 q 12.1$ \\
\hline hsa-miR-524-3p & $0.63 \pm 0.027$ & 0.00748 & $19 q 13.42$ \\
\hline hsa-miR-4632-3p & $0.63 \pm 0.282$ & 0.01632 & $1 \mathrm{p} 36.22$ \\
\hline hsa-miR-210-3p & $0.66 \pm 0.103$ & 0.0008 & $11 \mathrm{p} 15.5$ \\
\hline hsa-miR-6859-3p & $0.67 \pm 0.194$ & 0.01234 & $1 / 15 / 16$ \\
\hline
\end{tabular}

Table II. Expression changes and chromosomal locations of miRNAs in TKKK cells (gemcitabine resistant) treated with gemcitabine compared with non-treated cells.

\begin{tabular}{llll}
\hline & \multicolumn{2}{l}{ Fold (treated/untreated) } & \\
\cline { 2 - 3 } $\begin{array}{l}\text { Upregulated } \\
\text { miRNA }\end{array}$ & Mean \pm SD & p-value & $\begin{array}{c}\text { Chromosomal } \\
\text { localization }\end{array}$ \\
\hline hsa-miR-1238-3p & $2.03 \pm 0.337$ & 0.00328 & $19 \mathrm{p} 13.2$ \\
$\begin{array}{l}\text { Downregulated } \\
\text { miRNA }\end{array}$ & & & \\
hsa-miR-99a-5p & $0.42 \pm 0.191$ & 0.00527 & $21 \mathrm{q} 21.1$ \\
hsa-miR-664b-3p & $0.47 \pm 0.161$ & 0.00611 & Xq28 \\
hsa-miR-625-3p & $0.52 \pm 0.205$ & 0.02519 & $14 \mathrm{q} 23.3$ \\
hsa-miR-6087 & $0.54 \pm 0.232$ & 0.02987 & Xq22.3 \\
hsa-miR-6070 & $0.55 \pm 0.195$ & 0.00925 & $21 \mathrm{q} 22.3$ \\
hsa-miR-513a-5p & $0.57 \pm 0.229$ & 0.01055 & Xq27.3 \\
hsa-miR-502-3p & $0.57 \pm 0.088$ & 0.00092 & Xp11.23 \\
hsa-miR-492 & $0.59 \pm 0.431$ & 0.04099 & $12 \mathrm{q} 22$ \\
hsa-miR-484 & $0.59 \pm 0.270$ & 0.02036 & $16 \mathrm{p} 13.11$ \\
hsa-miR-4454 & $0.60 \pm 0.231$ & 0.00617 & $4 \mathrm{q} 32.2$ \\
hsa-miR-4417 & $0.62 \pm 0.239$ & 0.0202 & $1 \mathrm{p} 36.31$ \\
hsa-miR-3687 & $0.62 \pm 0.337$ & 0.01778 & $21 \mathrm{p} 11.2$ \\
hsa-miR-3652 & $0.63 \pm 0.227$ & 0.00968 & $12 \mathrm{q} 23.3$ \\
hsa-miR-3651 & $0.64 \pm 0.244$ & 0.03039 & $9 \mathrm{q} 22.31$ \\
hsa-miR-3184-3p & $0.66 \pm 0.174$ & 0.00723 & $17 \mathrm{q} 11.2$ \\
hsa-miR-3181 & $0.67 \pm 0.178$ & 0.01088 & $16 \mathrm{q} 12.1$ \\
\hline
\end{tabular}

significantly altered expression levels. In HuCCT-1 cells, these altered miRNAs may provide clues to the molecular basis of the gemcitabine anticancer effects.

Of note, the following tumor suppressor miRNAs were upregulated in gemcitabine-treated HuCCT-1 cells: miR-23b-3p, miR-22-3p, miR-29c, miR-660, let-7a, miR-146a, miR-214, miR-204, miR-100, miR-29a, miR-23a, miR-24 and miR-34a. 
Table III. Expression miR-6087, miR-3651 and miR-664b-3p was the opposite in the cell types (HuCCT-1, sensitive; TKKK, resistant) treated with gemcitabine.

\begin{tabular}{llc}
\hline & \multicolumn{2}{l}{ Fold (treated/untreated) Mean \pm SD } \\
\cline { 2 - 3 } miRNA & HuCCT-1 & TKKK \\
\hline hsa-miR-6087 & $3.66 \pm 0.651 \uparrow$ & $0.54 \pm 0.232 \downarrow$ \\
hsa-miR-3651 & $1.53 \pm 0.240 \uparrow$ & $0.64 \pm 0.244 \downarrow$ \\
hsa-miR-664b-3p & $1.50 \pm 0.376 \uparrow$ & $0.47 \pm 0.161 \downarrow$ \\
\hline
\end{tabular}

$\uparrow$, upregulation; $\downarrow$, downregulation.

These results suggest that the inhibition of cell proliferation by gemcitabine might be due to the induction of tumor suppressor miRNAs.

In previous studies, we demonstrated that members of the let-7 family, altered by the antidiabetic drug metformin, contribute to cell growth inhibition $(9,11)$. In the present study, gemcitabine upregulated let-7a in HuCCT-1 cells. The let-7 family contains 13 members and is recognized as a class of miRNAs that induce tumor-suppressing effects. Reduction of let-7 family members have been reported in various cancers, including lung cancer (26), breast cancer (27), colorectal cancer (28), gastric cancer (11), and hepatocellular carcinoma (29). The let-7 family members act as tumor suppressor molecules by binding target oncogenes, such as Ras (30), HMGA2 (31) and c-Myc (32). In addition, Liu et al reported that let-7a reduced c-Myc and the c-Myc target gene cyclin D1, leading to cell cycle arrest and the inhibition of proliferation (33). These events suggest that the suppression of cancer cell proliferation by gemcitabine may result, in part, from the upregulation of let-7a.

miR-214 inhibits cell growth in hepatocellular carcinoma (HCC) through suppression of $\beta$-catenin (34). In addition, miR-214 results in the suppression of cyclin D1, a downstream gene of the Wnt- $\beta$-catenin pathway (34). Since cyclin D1 is also a target of miR-34a in HCC (35), the upregulation of miR-34a reduces cyclin D1 expression (36). The upregulation of let-7a, miR-214 and miR-34a may reduce cyclin D1 in gemcitabinetreated HuCCT-1 cells.

Among the miRNAs downregulated in gemcitabinetreated HuCCT-1 cells, miR-1260b (37), miR-4286 (38), miR-222 (39-43) and miR-210 (44) were upregulated in several cancers. Collectively, the antitumor effects of gemcitabine in HuCCT-1 cells might be related to the reduction of these miRNAs. miR-1260b, in particular, has been recognized as an onco-miRNA, because the antitumor effect molecule genistein downregulates onco-miR-1260b and inhibits the Wnt- $\beta$-catenin signaling pathway, which is involved in cell growth (37). The Wnt- $\beta$-catenin signaling pathway is activated during CCC tumorigenesis (45). Therefore, the antitumor effect of gemcitabine might be associated with miR-1260b inhibition. miR-222 was also recognized as oncogenic miRNA (39-43). The cell cycle-dependent kinase inhibitor, p27Kip1 is the target gene of miR-222 $(39,40,43)$. Therefore, the downregulation of miR-222 led to G1 arrest. Based on previous studies, our data suggest that the altered miRNA, particularly, the downregulation of miR-1260b and miR-222, may result from the antitumor effect of gemcitabine.

In Tables I and II, miR-3181 is shown as downregulated in both HuCCT-1 and TKKK cells. These data suggest that the change in miR-3181 expression might not be involved in the antitumor effects of gemcitabine. In contrast, while miR-6087, miR-3651 and miR-664b-3p were upregulated in gemcitabinetreated HuCCT-1 cells, these miRNAs were downregulated in TKKK cells. The results suggest that modulations in miR-6087, miR-3651 and miR-664b-3p expression following gemcitabine treatment might be an important factor in determining whether cancer cells are sensitive to gemcitabine.

In conclusion, our results revealed that gemcitabine inhibits HuCCT-1 cell proliferation by suppressing cell cycle-related proteins, especially cyclin D1. In addition, alterations in miRNA expression after gemcitabine treatment contribute to gemcitabine resistance. Aberrant miRNA or target molecule expression would provide a mechanism for the treatment of CCC using gemcitabine.

\section{References}

1. Matsumoto K, Nagahara T, Okano J and Murawaki Y: The growth inhibition of hepatocellular and cholangiocellular carcinoma cells by gemcitabine and the roles of extracellular signal-regulated and checkpoint kinases. Oncol Rep 20: 863-872, 2008 .

2. Nakajima Y, Takagi H, Kakizaki S, Horiguchi N, Sato K, Sunaga N and Mori M: Gefitinib and gemcitabine coordinately inhibited the proliferation of cholangiocarcinoma cells. Anticancer Res 32: 5251-5262, 2012.

3. Iwaki J, Kikuchi K, Mizuguchi Y, Kawahigashi Y, Yoshida H, Uchida E and Takizawa T: MiR-376c down-regulation accelerates EGF-dependent migration by targeting GRB2 in the HuCCT1 human intrahepatic cholangiocarcinoma cell line. PLoS One 8: e69496, 2013

4. Patel T: New insights into the molecular pathogenesis of intrahepatic cholangiocarcinoma. J Gastroenterol 49: 165-172, 2014.

5. Jarnagin WR, Ruo L, Little SA, Klimstra D, D'Angelica M, DeMatteo RP, Wagman R, Blumgart LH and Fong Y: Patterns of initial disease recurrence after resection of gallbladder carcinoma and hilar cholangiocarcinoma: Implications for adjuvant therapeutic strategies. Cancer 98: 1689-1700, 2003.

6. Meng F, Henson R, Lang M, Wehbe H, Maheshwari S, Mendell JT, Jiang J, Schmittgen TD and Patel T: Involvement of human micro-RNA in growth and response to chemotherapy in human cholangiocarcinoma cell lines. Gastroenterology 130: 2113-2129, 2006

7. Valle J, Wasan H, Palmer DH, Cunningham D, Anthoney A, Maraveyas A, Madhusudan S, Iveson T, Hughes S, Pereira SP, et al; ABC-02 Trial Investigators: Cisplatin plus gemcitabine versus gemcitabine for biliary tract cancer. N Engl J Med 362: 1273-1281, 2010

8. Morizane C, Okusaka T, Mizusawa J, Takashima A, Ueno M, Ikeda M, Hamamoto Y, Ishii H, Boku N and Furuse J: Randomized phase II study of gemcitabine plus S-1 versus S-1 in advanced biliary tract cancer: A Japan Clinical Oncology Group trial (JCOG 0805). Cancer Sci 104: 1211-1216, 2013.

9. Miyoshi H, Kato K, Iwama H, Maeda E, Sakamoto T, Fujita K, Toyota Y, Tani J, Nomura T, Mimura S, et al: Effect of the antidiabetic drug metformin in hepatocellular carcinoma in vitro and in vivo. Int J Oncol 45: 322-332, 2014.

10. Haga H, Yan I, Takahashi K, Wood J and Patel T: Emerging insights into the role of microRNAs in the pathogenesis of cholangiocarcinoma. Gene Expr 16: 93-99, 2014.

11. Kato K, Gong J, Iwama H, Kitanaka A, Tani J, Miyoshi H, Nomura K, Mimura S, Kobayashi M, Aritomo Y, et al: The antidiabetic drug metformin inhibits gastric cancer cell proliferation in vitro and in vivo. Mol Cancer Ther 11: 549-560, 2012.

12. Kobayashi M, Kato K, Iwama H, Fujihara S, Nishiyama N, Mimura S, Toyota Y, Nomura T, Nomura K, Tani J, et al: Antitumor effect of metformin in esophageal cancer: In vitro study. Int J Oncol 42: 517-524, 2013. 
13. Bradford MM: A rapid and sensitive method for the quantitation of microgram quantities of protein utilizing the principle of protein-dye binding. Anal Biochem 72: 248-254, 1976.

14. Laemmli UK: Cleavage of structural proteins during the assembly of the head of bacteriophage T4. Nature 227: 680-685, 1970.

15. Towbin H, Staehelin T and Gordon J: Electrophoretic transfer of proteins from polyacrylamide gels to nitrocellulose sheets: Procedure and some applications. Proc Natl Acad Sci USA 76: 4350-4354, 1979.

16. Masaki T, Okada M, Shiratori Y, Rengifo W, Matsumoto K, Maeda S, Kato N, Kanai F, Komatsu Y, Nishioka M, et al: pp60c-src activation in hepatocellular carcinoma of humans and LEC rats. Hepatology 27: 1257-1264, 1998.

17. Masaki T, Shiratori Y, Rengifo W, Igarashi K, Matsumoto K, Nishioka M, Hatanaka Y and Omata M: Hepatocellular carcinoma cell cycle: Study of Long-Evans cinnamon rats. Hepatology 32: 711-720, 2000.

18. Morishita A, Masaki T, Yoshiji H, Nakai S, Ogi T, Miyauchi Y, Yoshida S, Funaki T, Uchida N, Kita Y, et al: Reduced expression of cell cycle regulator p18(INK4C) in human hepatocellular carcinoma. Hepatology 40: 677-686, 2004.

19. Katsura A, Morishita A, Iwama H, Tani J, Sakamoto T, Tatsuta M, Toyota Y, Fujita K, Kato K, Maeda E, et al: MicroRNA profiles following metformin treatment in a mouse model of nonalcoholic steatohepatitis. Int J Mol Med 35: 877-884, 2015.

20. Anderson CD, Pinson CW, Berlin J and Chari RS: Diagnosis and treatment of cholangiocarcinoma. Oncologist 9: 43-57, 2004.

21. Wang Y, Zhou Y, Zhou H, Jia G, Liu J, Han B, Cheng Z, Jiang H, Pan S and Sun B: Pristimerin causes G1 arrest, induces apoptosis, and enhances the chemosensitivity to gemcitabine in pancreatic cancer cells. PLoS One 7: e43826, 2012.

22. Hong DS, Angelo LS and Kurzrock R: Interleukin-6 and its receptor in cancer: Implications for translational therapeutics. Cancer 110: 1911-1928, 2007.

23. Waugh DJJ and Wilson C: The interleukin-8 pathway in cancer Clin Cancer Res 14: 6735-6741, 2008.

24. Okabe H, Beppu T, Ueda M, Hayashi H, Ishiko T, Masuda T, Otao R, Horlad H, Mima K, Miyake K, et al: Identification of CXCL5/ENA-78 as a factor involved in the interaction between cholangiocarcinoma cells and cancer-associated fibroblasts. Int J Cancer 131: 2234-2241, 2012.

25. Salcedo R, Ponce ML, Young HA, Wasserman K, Ward JM, Kleinman HK, Oppenheim JJ and Murphy WJ: Human endothelial cells express CCR2 and respond to MCP-1: Direct role of $\mathrm{MCP}-1$ in angiogenesis and tumor progression. Blood 96: 34-40, 2000.

26. Takamizawa J, Konishi H, Yanagisawa K, Tomida S, Osada H, Endoh H, Harano T, Yatabe Y, Nagino M, Nimura Y, et al: Reduced expression of the let-7 microRNAs in human lung cancers in association with shortened postoperative survival. Cancer Res 64: 3753-3756, 2004.

27. Yu F, Yao H, Zhu P, Zhang X, Pan Q, Gong C, Huang Y, Hu X, Su F, Lieberman J, et al: let-7 regulates self renewal and tumorigenicity of breast cancer cells. Cell 131: 1109-1123, 2007

28. Akao Y, Nakagawa Y and Naoe T: let-7 microRNA functions as a potential growth suppressor in human colon cancer cells. Biol Pharm Bull 29: 903-906, 2006.

29. Zhu X-M, Wu L-J, Xu J, Yang R and Wu F-S: Let-7c microRNA expression and clinical significance in hepatocellular carcinoma. J Int Med Res 39: 2323-2329, 2011.
30. Johnson SM, Grosshans H, Shingara J, Byrom M, Jarvis R, Cheng A, Labourier E, Reinert KL, Brown D and Slack FJ: RAS is regulated by the let-7 microRNA family. Cell 120: 635-647, 2005.

31. Lee YS and Dutta A: The tumor suppressor microRNA let-7 represses the HMGA2 oncogene. Genes Dev 21: 1025-1030, 2007.

32. Osada $\mathrm{H}$ and Takahashi T: let-7 and miR-17-92: Small-sized major players in lung cancer development. Cancer Sci 102: 9-17, 2011.

33. Liu Y, Yin B, Zhang C, Zhou L and Fan J: Hsa-let-7a functions as a tumor suppressor in renal cell carcinoma cell lines by targeting c-myc. Biochem Biophys Res Commun 417: 371-375, 2012.

34. Wang X, Chen J, Li F, Lin Y, Zhang X, Lv Z and Jiang J: MiR-214 inhibits cell growth in hepatocellular carcinoma through suppression of $\beta$-catenin. Biochem Biophys Res Commun 428: 525-531, 2012.

35. Xiao Z, Li CH, Chan SL, Xu F, Feng L, Wang Y, Jiang JD, Sung JJ, Cheng $\mathrm{CH}$ and Chen Y: A small-molecule modulator of the tumor-suppressor miR34a inhibits the growth of hepatocellular carcinoma. Cancer Res 74: 6236-6247, 2014.

36. Guo Y, Li S, Qu J, Wang S, Dang Y, Fan J, Yu S and Zhang J: MiR-34a inhibits lymphatic metastasis potential of mouse hepatoma cells. Mol Cell Biochem 354: 275-282, 2011.

37. Hirata H, Ueno K, Nakajima K, Tabatabai ZL, Hinoda Y, Ishi N and Dahiya R: Genistein downregulates onco-miR-1260b and inhibits Wnt-signalling in renal cancer cells. Br J Cancer 108: 2070-2078, 2013.

38. Sand M, Skrygan M, Sand D, Georgas D, Gambichler T, Hahn SA, Altmeyer P and Bechara FG: Comparative microarray analysis of microRNA expression profiles in primary cutaneous malignant melanoma, cutaneous malignant melanoma metastases, and benign melanocytic nevi. Cell Tissue Res 351: 85-98, 2013.

39. Yang Y-F, Wang F, Xiao J-J, Song Y, Zhao YY, Cao Y, Bei YH and Yang CQ: MiR-222 overexpression promotes proliferation of human hepatocellular carcinoma HepG2 cells by downregulating p27. Int J Clin Exp Med 7: 893-902, 2014.

40. Sun C, Li N, Zhou B, Yang Z, Ding D, Weng D, Meng L, Wang S, Zhou J, Ma D, et al: $\mathrm{miR}-222$ is upregulated in epithelial ovarian cancer and promotes cell proliferation by downregulating P27(kip1). Oncol Lett 6: 507-512, 2013.

41. Saito Y, Suzuki H, Matsuura M, Sato A, Kasai Y, Yamada K, Saito $\mathrm{H}$ and Hibi T: MicroRNAs in hepatobiliary and pancreatic cancers. Front Genet 2: 66, 2011.

42. Chun-Zhi Z, Lei H, An-Ling Z, Yan-Chao F, Xiao Y, Guang-Xiu W, Zhi-Fan J, Pei-Yu P, Qing-Yu Z and Chun-Sheng K: MicroRNA-221 and microRNA-222 regulate gastric carcinoma cell proliferation and radioresistance by targeting PTEN. BMC Cancer 10: 367, 2010.

43. Visone R, Russo L, Pallante P, De Martino I, Ferraro A, Leone V, Borbone E, Petrocca F, Alder H, Croce CM, et al: MicroRNAs (miR)-221 and miR-222, both overexpressed in human thyroid papillary carcinomas, regulate p27Kip1 protein levels and cell cycle. Endocr Relat Cancer 14: 791-798, 2007.

44. Võsa U, Vooder T, Kolde R, Vilo J, Metspalu A and Annilo T: Meta-analysis of microRNA expression in lung cancer. Int $\mathrm{J}$ Cancer 132: 2884-2893, 2013.

45. Sugimachi K, Aishima S, Taguchi K, Tanaka S, Shimada M, Kajiyama K, Sugimachi K and Tsuneyoshi M: The role of overexpression and gene amplification of cyclin D1 in intrahepatic cholangiocarcinoma. J Hepatol 35: 74-79, 2001. 